Article

\title{
Curcumin Inhibits the Primary Nucleation of Amyloid-Beta Peptide: A Molecular Dynamics Study
}

\author{
Irini Doytchinova ${ }^{1, *(\mathbb{C}}$, Mariyana Atanasova ${ }^{1}$, Evdokiya Salamanova ${ }^{1}$, Stefan Ivanov ${ }^{1,2}(\mathbb{C}$ and \\ Ivan Dimitrov ${ }^{1} \mathbb{D}$ \\ 1 Faculty of Pharmacy, Medical University of Sofia, 2 Dunav st., 1000 Sofia, Bulgaria; \\ matanasova@pharmfac.mu-sofia.bg (M.A.); esalamanova@bio21.bas.bg (E.S.); \\ ivanovs@umd.edu (S.I.); idimitrov@pharmfac.mu-sofia.bg (I.D.) \\ 2 Institute for Bioscience and Biotechnology Research, University of Maryland, Rockville, MD 20850, USA \\ * Correspondence: idoytchinova@pharmfac.mu-sofia.bg; Tel./Fax: +359-29236506
}

Received: 5 August 2020; Accepted: 12 September 2020; Published: 15 September 2020

\begin{abstract}
The amyloid plaques are a key hallmark of neurodegenerative diseases such as Alzheimer's disease and Parkinson's disease. Amyloidogenesis is a complex long-lasting multiphase process starting with the formation of nuclei of amyloid peptides: a process assigned as a primary nucleation. Curcumin (CU) is a well-known inhibitor of the aggregation of amyloid-beta $(A \beta)$ peptides. Even more, $\mathrm{CU}$ is able to disintegrate preformed $\mathrm{A} \beta$ firbils and amyloid plaques. Here, we simulate by molecular dynamics the primary nucleation process of $12 \mathrm{~A} \beta$ peptides and investigate the effects of $C U$ on the process. We found that $C U$ molecules intercalate among the $A \beta$ chains and bind tightly to them by hydrogen bonds, hydrophobic, $\pi-\pi$, and cation $-\pi$ interactions. In the presence of $C U$, the $A \beta$ peptides form a primary nucleus of a bigger size. The peptide chains in the nucleus become less flexible and more disordered, and the number of non-native contacts and hydrogen bonds between them decreases. For comparison, the effects of the weaker $A \beta$ inhibitor ferulic acid (FA) on the primary nucleation are also examined. Our study is in good agreement with the observation that taken regularly, $\mathrm{CU}$ is able to prevent or at least delay the onset of neurodegenerative disorders.
\end{abstract}

Keywords: amyloid-beta peptide; curcumin; ferulic acid; molecular dynamics

\section{Introduction}

Amyloidogenic peptides and proteins are soluble structures that are able to aggregate into insoluble amyloid fibrils with a characteristic core structure rich in $\beta$-sheets [1]. Evolutionary, these proteins have appeared in the microorganisms as necessary components of physiological functions such as biofilm formation [2], cell adhesion [3], interactions with host membranes [4], and permeabilization [5]. In humans, some of them also show physiological functions. For example, amylin is involved in the regulation of insulin and glucagon secretion [6], tau protein stabilizes the microtubules in the cells [7], the amyloid-beta peptide controls the synaptic activity [8] and acts as a protective agent against brain infections [9,10], $\alpha$-synuclein regulates the neurotransmitter release [11], and premalanosome protein (PMEL) forms fibrils in the melanocytes required for the optimal cell function [12]. At the same time, the ability of amyloidogenic proteins to form fibrils is a key feature of more than 50 diseases such as Alzheimer's disease [13], Parkinson's disease [14], prion disease [15], type 2 diabetes [16], and sickle-cell anemia [17]. The triggers that convert the functional amyloids into pathological ones still remain unclear.

The amyloid fibril formation is a complex process consisting of three phases: nucleation, elongation, and saturation [18]. The nucleation starts with the aggregation of two monomers into a dimer, which further attracts other monomers and evolves into an oligomer. The oligomer might arrange into 
toxic fibrillar aggregate (on-pathway) or into non-toxic disordered aggregate (off-pathway). The toxic fibrils elongate by attaching novel monomers in an appropriate cross- $\beta$-conformation. In the saturation phase, the fibril formation reaches equilibrium as monomers detach and attach continuously at the ends of the fibril. The nucleation could be primary or secondary. A primary nucleation is assigned to the creation of a folding nucleus, from which oligomeric and fibrillar assemblies emanate [19], while the secondary nucleation describes the formation of nuclei around pre-existing crystals [20].

As the nucleation phase is the initial step in the process of fibril formation, inhibition of the aggregation of amyloidogenic peptides and proteins is one of the therapeutic strategies in the development of anti-amyloid drug candidates [21]. It was reported that curcumin (CU), rosmarinic acid, nordihydroquaiaretic acid, rifampicin, and wine-related polyphenols, such as myricetin, dose-dependently inhibit amyloid-beta $(A \beta)$ fibril formation from $A \beta_{1-40}$ and $A \beta_{1-42}$ and destabilize preformed $A \beta$ fibrils in vitro [22].

$\mathrm{CU}$, a polyphenol from Curcuma longa (turmeric plant), is known to treat many diseases, including neurodegenerative ones such as Alzheimer's disease, Parkinson's disease, prion disease, multiple sclerosis, stroke, anxiety, and depression [23]. It has been observed that the death rate of Alzheimer's/dementia per 100,000 population standardized by age in India is significantly lower than in the Middle East [24]. One of the reasons could be the regular intake of turmeric in the routine diet of Indians [25]. CU is a widely studied compound, and many good reviews on its properties and applications are available in the literature [23,26-30]. It was found in vitro that CU blocks the toxicity of $\mathrm{A} \beta$ oligomers $\left(\mathrm{IC}_{50}=0.8 \mu \mathrm{M}\right)[31]$ and disintegrates preformed $\mathrm{A} \beta$ fibrils $\left(\mathrm{EC}_{50}=1 \mu \mathrm{M}\right)$ [32]. In animals, it was shown that $C U$ reduces insoluble $A \beta$ deposits [33] and amyloid plaques [31]. $C U$ formulations with improved bioavailability have been demonstrated to improve memory, mood, and alertness in clinical trials with non-demented elderly patients [34,35].

The interactions of $C U$ with $A \beta$ peptides and fibrils have been simulated by molecular dynamics (MD). Zhao et al. have studied the effects of $C U$ on the stability of $A \beta$ dimers and have found that $C U$ acts as $\beta$-sheet breaker, reducing the $\beta$-sheet content within the $A \beta$ oligomers [36]. Awasthi et al. have analyzed the effects of $\mathrm{CU}$ on the stability of two familial $\mathrm{A} \beta 42$ mutations-A2V (harmful) and $\mathrm{A} 2 \mathrm{~T}$ (protective) - and have found that the mutant $\mathrm{A} 2 \mathrm{~V}$ is more stable than $\mathrm{A} 2 \mathrm{~T}$ in the absence of $\mathrm{CU}$, while $\mathrm{A} 2 \mathrm{~T}$ is more stable in the presence of $\mathrm{CU}$ [37]. Apart from oligomers, $\mathrm{CU}$ binds tightly to preform $\mathrm{A} \beta$ fibrils occupying the binding pocket inside fibrils [38]. It forms hydrogen bonds and hydrophobic interactions with protofibrils [38,39] and causes structural distortion and perturbation [39,40], leading to the dissociation of the outermost peptides [41]. The number of intermolecular backbone hydrogen bonds between adjacent $\beta$-threats in fibrils correlates with the anti-aggregation activity of $A \beta$ inhibitors [42].

The aim of the present study was to simulate by MD the primary nucleation of an ensemble of $12 \mathrm{~A} \beta_{1-42}$ peptides and to analyze the effects of the inhibitor curcumin. For comparison, the effects of the weaker inhibitor ferulic acid (FA) $\left(\mathrm{IC}_{50}=5.5 \mu \mathrm{M}\right)$ [43] were also conducted.

\section{Models and Method}

\subsection{Modeled Ligands and Systems}

The chemical structures of CU (CID 969516) and FA (CID 445858) were retrieved from PubChem [44] (Figure 1). The keto-enol form of CU was used in the present study instead of $\beta$-diketone, as it has been proven that the keto-enol form exhibits anti-aggregatation properties and is responsible for the ability of $C U$ to prevent $A \beta$ oligomer and fibril assembly $[45,46]$. FA is a weak acid with $\mathrm{pK}_{\mathrm{a}} 4.58$ and at physiological $\mathrm{pH} 7.4$, the anionic form dominates. This form was used in the simulations. The molecules were parameterized by GAFF 2.11 [47] with AM1-BCC charges [48] before being used in Amber 18 [49]. The $A \beta_{1-42}$ monomer structure was obtained from PDB (Protein Database); ( $p d b$ code 1IYT) [50]. Both ends were capped, and all hydrogens were added. 
<smiles>COc1cc(/C=C/C(=O)CC(O)/C=C/c2ccc(O)c(OC)c2)ccc1O</smiles>

(A) Curcumin (CU)<smiles>COc1cc(/C=C/C(=O)O)ccc1O</smiles>

(B) Ferulic acid (FA)

Figure 1. Chemical structures of the amyloid-beta $(A \beta)$ inhibitor $(A)$ curcumin $(C U)$ and $(B)$. non-inhibitor ferulic acid (FA).

Five systems were modeled (Figure 2). The first one contained $12 \mathrm{~A} \beta_{1-42}$ monomers randomly positioned in a truncated octahedron cell with a volume of $1,927,025 \AA^{3}$ and solvated with TIP3P water yielding $10.4 \mathrm{mM}$ solution. $\mathrm{NaCl}$ was added to maintain a physiological salt concentration and adjusted to neutralize the peptides' charge. This system was used for the construction of the other four systems. Two of them contained 12 and $36 \mathrm{CU}$ molecules spread randomly around the $\mathrm{A} \beta$ monomers corresponding to $9.3 \mathrm{mM}$ and $30.4 \mathrm{mM}$ solutions, respectively. The last two systems included 12 and $36 \mathrm{FA}$ anions placed around the $\mathrm{A} \beta$ monomers, giving $10.3 \mathrm{mM}$ and $31.2 \mathrm{mM}$ solutions, respectively. The salt concentration was adjusted additionally to neutralize the FA charge.

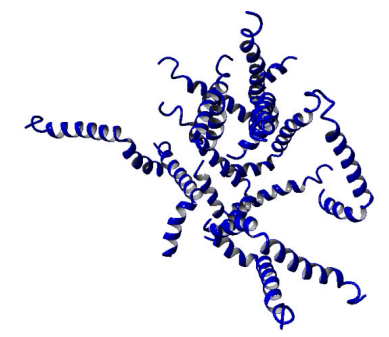

(A)

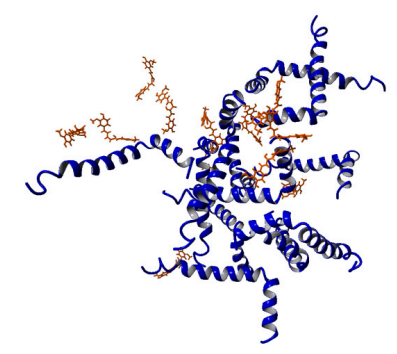

(B)

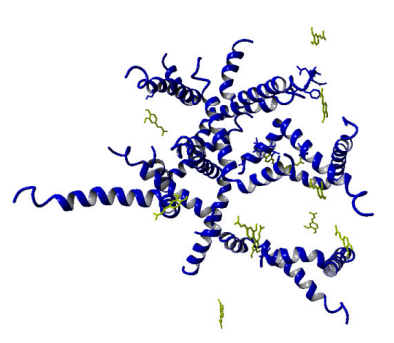

(D)

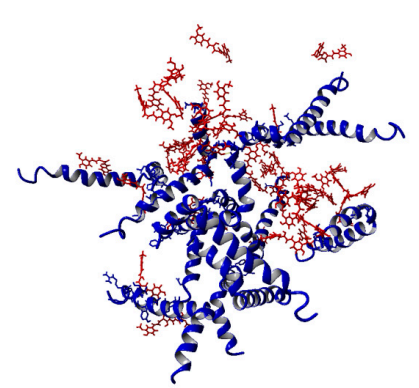

(C)

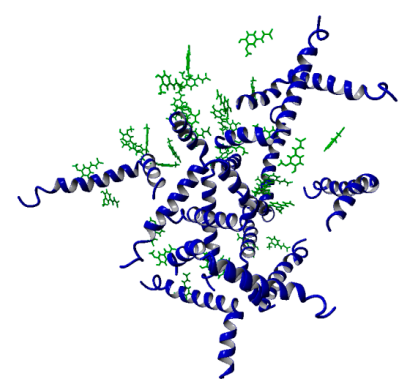

(E)

Figure 2. Modeled systems in the present study: (A) $12 \mathrm{~A} \beta$ monomers; (B) $12 \mathrm{~A} \beta$ monomers and $12 \mathrm{CU}$ molecules; (C) $12 \mathrm{~A} \beta$ monomers and $36 \mathrm{CU}$ molecules; (D) $12 \mathrm{~A} \beta$ monomers and $12 \mathrm{FA}$ anions; (E) $12 \mathrm{~A} \beta$ monomers and $36 \mathrm{FA}$ anions. 


\subsection{Protocol}

Initially, the solvated systems were energy minimized for 5000 steps with $3 \mathrm{kcal} / \mathrm{mol} \AA^{2}$ harmonic restraints on solute heavy atoms, followed by heating them from 0 to $300 \mathrm{~K}$ over a period of $1 \mathrm{~ns}$ at constant volume with identical restraints. Next, the systems were equilibrated for $1 \mathrm{~ns}$ of constant pressure density with restraints and for $100 \mathrm{~ns}$ without any restraints. Finally, they were simulated for $1000 \mathrm{~ns}$ of production dynamics under constant temperature $(310 \mathrm{~K})$ and pressure $(1 \mathrm{bar})$, maintained with the Langevin thermostat [51] and Berendsen barostat [52], respectively. The systems were simulated with the ff14SB [53] force field under periodic boundary conditions. A $12.0 \AA$ cutoff was used for both van der Waals and electrostatic interactions; long-range electrostatics beyond the real-space cutoff were evaluated with the particle-mesh Ewald (PME) scheme [54]. During heating, density equilibration, preproduction, and production dynamics, covalent bonds involving hydrogen were constrained using the SHAKE algorithm [55], allowing a 2 fs time step; only during energy minimization were the bonds to hydrogen were not constrained. During production dynamics, frames were saved every $1 \mathrm{~ns}$ for a total of 1000 per trajectory to be used in subsequent analysis. The MD simulations were performed by Amber 18 [56] and were analyzed by cpptraj V4.24.0 [57].

\section{Results}

The five modeled $\mathrm{A} \beta$ ensembles-12 $\mathrm{A} \beta_{1-42}$ monomers $(10.4 \mathrm{mM}), 12 \mathrm{~A} \beta_{1-42}$ monomers $+12 \mathrm{CU}$ molecules $(9.3 \mathrm{mM}), 12 \mathrm{~A} \beta_{1-42}$ monomers $+36 \mathrm{CU}$ molecules $(30.4 \mathrm{mM}), 12 \mathrm{~A} \beta_{1-42}$ monomers $+12 \mathrm{FA}$ anions $(10.3 \mathrm{mM})$, and $12 \mathrm{~A} \beta_{1-42}$ monomers + $36 \mathrm{FA}$ anions $(31.2 \mathrm{mM}$ ) (Figure 2)-were simulated in saliva for $1 \mu \mathrm{s}$ according to the MD protocol described in Models and Methods. The modeled $A \beta$ ensembles formed stable nuclei for a different period of time. The coordinate trajectories were processed and used to analyze the effects of $\mathrm{CU}$ and FA on the process of primary nucleation of A $\beta$ peptides.

\subsection{Curcumin Stabilizes Immediately the $A \beta_{1-42}$ Ensemble}

The averaged backbone RMSDs (root mean square deviations) of the ensembles of $12 \mathrm{~A} \beta_{1-42}$ peptides with and without ligands were calculated as a function of time (Figure S1). The ensemble without a ligand underwent conformational distortions during the initial 300 frames ( $300 \mathrm{~ns}$ ) and then was stabilized (Figure S1A). The presence of a ligand stabilizes the $\mathrm{A} \beta$ ensemble earlier. In the presence of $12 \mathrm{CU}$ molecules, the ensemble was stabilized for $8 \mathrm{~ns}$ (Figure S1C); in the presence of $36 \mathrm{CU}$, it was stabilized for $2 \mathrm{~ns}$ (Figure S1E); in the presence of 12 FA, it was stabilized for $20 \mathrm{~ns}$ (Figure S1G); and in the presence of $36 \mathrm{FA}$, it was stabilized for $15 \mathrm{~ns}$ (Figure S1I). It is clearly evident that the presence of $\mathrm{CU}$ molecules stabilizes immediately the ensemble in a dose-dependent manner. Two additional $50 \mathrm{~ns}$ productions on the five systems were run. They confirmed the immediate stabilizing effect of $\mathrm{CU}$ (Figure S2).

The backbone RMSFs (root mean square fluctuations) indicate the most fluctuating A $\beta$ residues during the MD simulation. Typically, the terminals of the A $\beta$ peptides fluctuate more than the middle parts, with the N-terminals being the most flexible. The averaged RMSFs of the ensembles of $12 \mathrm{~A} \beta$ peptides with and without ligands are summarized in Figure 3A. The presence of any ligand reduces the fluctuations of the $A \beta$ ensemble. The effects of $C U$ are more prominent than the effects of FA. $\mathrm{CU}$ decreases mainly the fluctuations of the C-terminals (Figure S1D,F). 


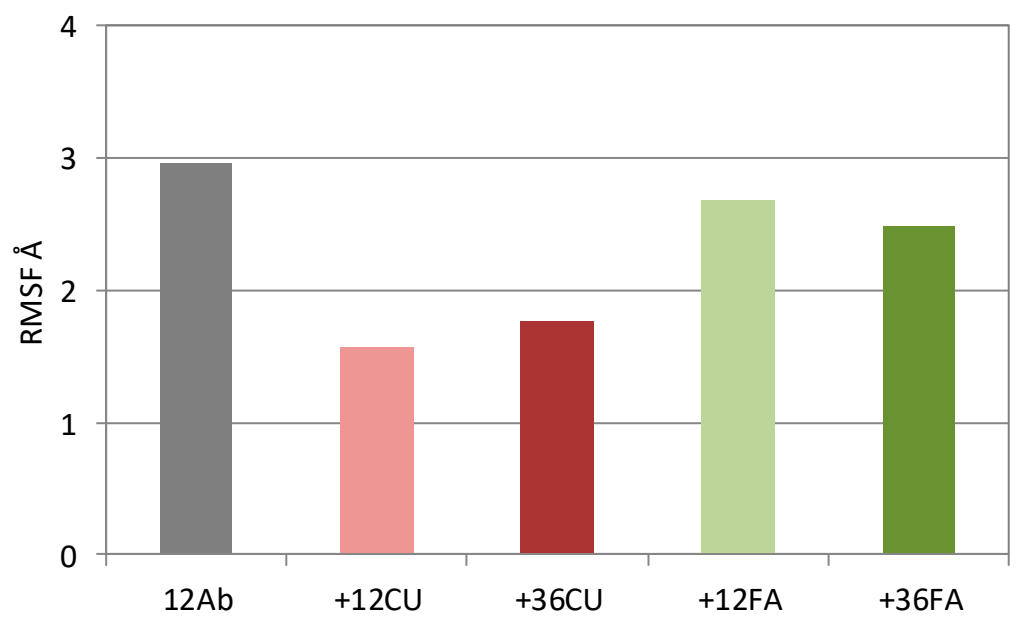

(A)

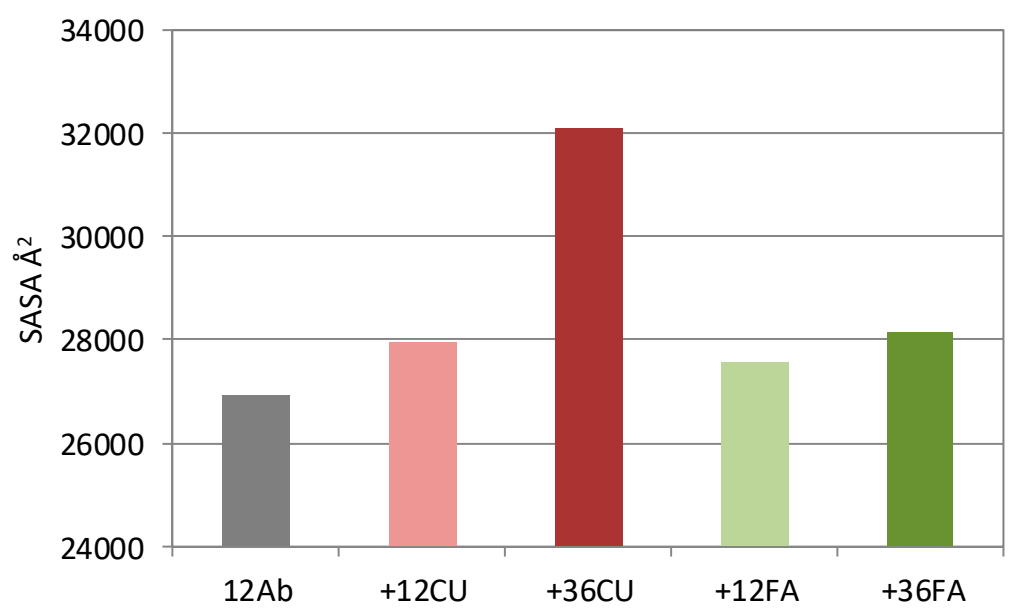

(B)

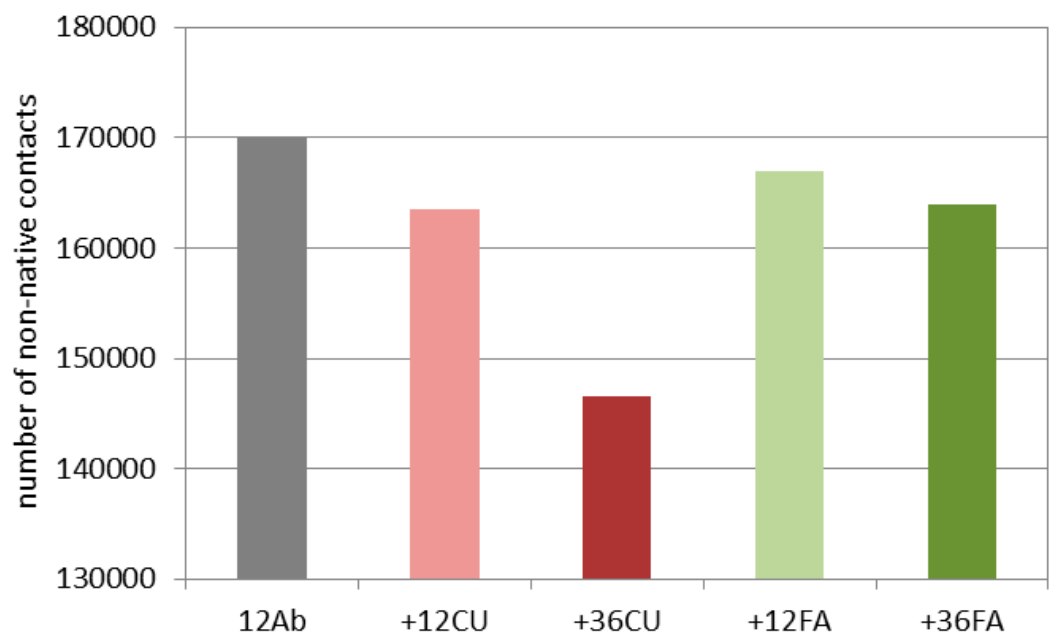

(C)

Figure 3. Cont. 


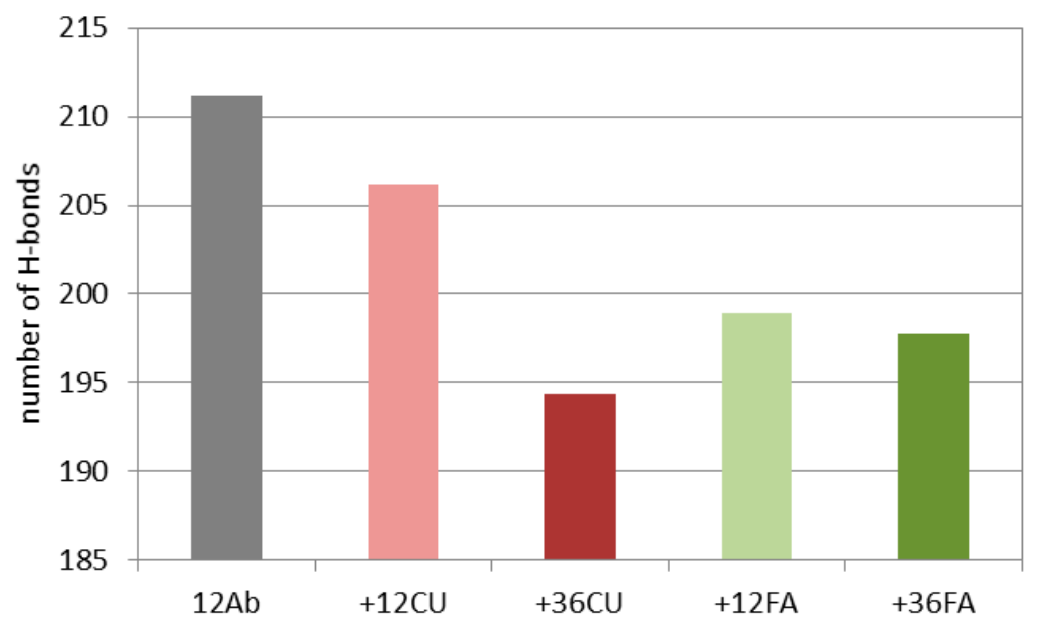

(D)

Figure 3. Root mean square fluctuations (RMSF) (A), solvent-accessible surface area (SASA) (B), number of non-native contacts $(\mathbf{C})$, and number of H-bonds (D) averaged over 1000 frames (1000 ns) for $12 \mathrm{~A} \beta$ monomers (gray), $12 \mathrm{~A} \beta$ monomers and $12 \mathrm{CU}$ molecules (pink), $12 \mathrm{~A} \beta$ monomers and $36 \mathrm{CU}$ molecules (red), $12 \mathrm{~A} \beta$ monomers and 12 FA anions (light green), $12 \mathrm{~A} \beta$ monomers and 36 FA anions (dark green).

\subsection{Curcumin Binds inside the A $\beta$ Nucleus}

The coordinates of the modeled systems after $1 \mu \mathrm{s}$ MD simulations are given in Figure 4. In $300 \mathrm{~ns}$, the $12 \mathrm{~A} \beta$ monomers collapsed into a compact nucleus losing part of the ordered structures ( $\alpha$-helix, 3-10 helix, $\beta$-turn) (Figure S2). The $A \beta_{1-42}$ peptide is a water-soluble molecule containing 20 hydrophobic residues (Ala, Ile, Leu, Met, Val, Phe, Tyr, and Trp) clustered mainly in the middle part of the molecule and in the C-terminal. The $\mathrm{A} \beta_{1-42}$ peptide has an overall $\log \mathrm{P}-12.2$ [44] and isoelectric point pI 5.5 [58]. In polar medium, the flexible peptide chains adopt spontaneously a globular conformation with a polar surface and non-polar core (Figure 4A). As a typical hydrophobic interaction, the nucleation is an entropy-driven process governed by an increase of solvent entropy.

Regardless of the concentrations, all molecules of the strong inhibitor $\mathrm{CU}$ were bound to $\mathrm{A} \beta$ peptides (Figure $4 \mathrm{~B}, \mathrm{C}$ ). Some of them were intercalated and bound inside the core, while others covered the surface. The main interactions between $C U$ and $A \beta$ residues were hydrophobic, but $\pi-\pi$ interactions with the side chains of Phe4, Tyr10, Phe19, and Phe20 and cation- $\pi$ interactions with the side chains of Arg5, Lys16, and Lys28 also occurred. Plenty of H-bonds exist between CU molecules and $A \beta$ residues. The hydrogen bonds in the ensembles are considered in detail in Section 3.6.

The $A \beta$ ensemble has quite a different look in the presence of the weak inhibitor FA (Figure $4 \mathrm{D}, \mathrm{E}$ ). In the presence of $12 \mathrm{FA}$, after $1 \mu$ s simulation, nine of them (75\%) were bound to $\mathrm{A} \beta$ peptides, while in the presence of $36 \mathrm{FA}$, this number was only $18(50 \%)$. Here again, the main interactions between the FA molecules and $A \beta$ peptides were hydrophobic. Most of the bound molecules made $\pi-\pi$ stacking with the aromatic side chains of Phe4, Tyr10, Phe19, and Phe20. Cation- $\pi$ interactions appeared between the phenyl ring of FA and the side chains of Arg5, Lys16, and Lys28. The hydrogen bonds between A $\beta$ and FA anions are considered in detail in Section 3.6.

Both ligands disrupted the salt bridges formed between the $\mathrm{A} \beta$ chains. Their number decreases from 142 (without ligands) to 121 (with $12 \mathrm{CU}$ ), 119 (with $36 \mathrm{CU}$ ), 123 (with $12 \mathrm{FA}$ ), and 118 (with 36 FA). The salt bridges were formed between Asp1, Asp7, Asp23, Glu3, Glu22, Arg5, Lys16, and Lys28. 


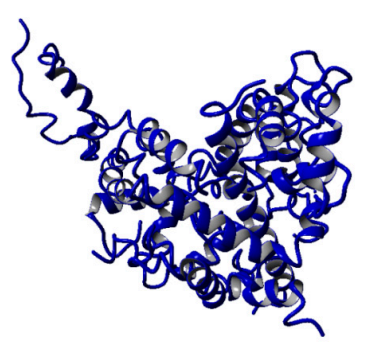

(A)

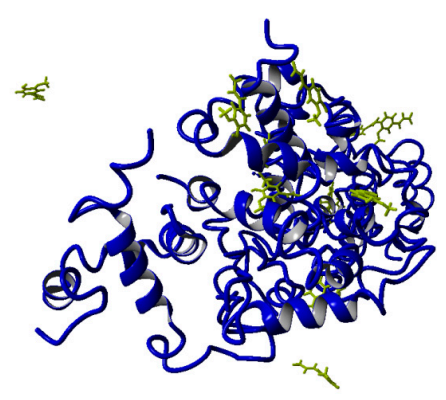

(D)
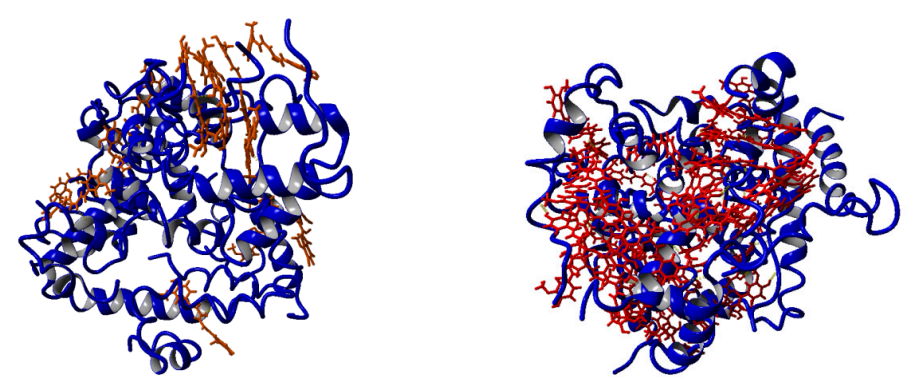

(B)
(C)

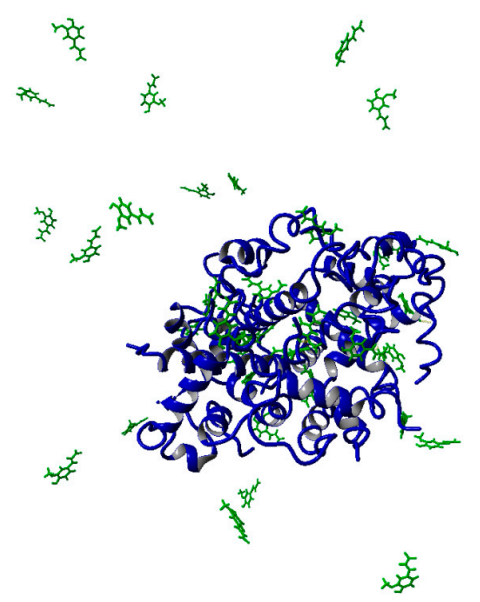

(E)

Figure 4. The modeled systems after $1 \mu$ s molecular dynamics (MD) simulation: (A) 12 A $\beta$ monomers; (B) $12 \mathrm{~A} \beta$ monomers and $12 \mathrm{CU}$ molecules; (C) $12 \mathrm{~A} \beta$ monomers and $36 \mathrm{CU}$ molecules; (D) $12 \mathrm{~A} \beta$ monomers and 12 FA anions; (E) $12 \mathrm{~A} \beta$ monomers and 36 FA anions.

\subsection{Curcumin Does Not Affect the Secondary Structures of the Peptides in the $A \beta_{1-42}$ Ensemble}

The analysis of the secondary structures of the $\mathrm{A} \beta$ peptides indicates that the ensembles with and without ligands underwent similar changes during the simulations. The total structural propensities over the initial and final $100 \mathrm{~ns}$ are given in Figure S3. The propensities of helices (including 3-10 helices) decreased by $8 \%$ (12 A $\beta$ ) to $18 \%$ (12 A $\beta+12 \mathrm{FA})$. The $\beta$-turn propensities decreased for the ensembles of $12 \mathrm{~A} \beta$ peptides, $12 \mathrm{~A} \beta+12 \mathrm{CU}$, and $12 \mathrm{~A} \beta+36 \mathrm{FA}$, for the ensemble of $12 \mathrm{~A} \beta+12 \mathrm{FA}$, they increased, and the ensemble of $12 \mathrm{~A} \beta+36 \mathrm{CU}$ remained almost unchanged. The bending propensities in all ensembles increased by $13 \%$ ( $12 \mathrm{~A} \beta+36 \mathrm{FA})$ to $23 \%$ (12 A $\beta+36 \mathrm{CU})$. Indeed, the nucleation proceeds by bending and losing the helical and $\beta$-turn structures (Figure 4 ). The final ensembles are nuclei of randomly folded chains. A distinguishable effect of $\mathrm{CU}$ on the secondary structures of $\mathrm{A} \beta$ peptides during the $1 \mu$ s simulation of the process of nucleation was not observed.

\subsection{Curcumin Increases the Solvent-Accessible Surface Area (SASA) of the A $\beta_{1-42}$ Ensemble}

The solvent-accessible surface area (SASA) was calculated using the algorithm of Weiser et al. [59] and expressed in $\AA^{2}$. The SASAs of the five ensembles averaged over 1000 frames are given in Figure 3B. CU at higher concentration (36 CU) increases the SASA of the $12 \mathrm{~A} \beta$ ensemble by $20 \%$. At lower concentration (12 CU), the increase is only $4 \%$ comparable to the increase caused by $12 \mathrm{FA}$ and $36 \mathrm{FA}$. The increased surface area is associated by the many CU molecules bound among the folded A $\beta$ chains (Figure 4 ). 


\subsection{Curcumin Decreases the Number of Non-Native Contacts in the $A \beta_{1-42}$ Ensemble}

Amber defines as a non-native contact any contact between a pair of atoms satisfying the distance cutoff (by default $7 \AA$ ), which is not already a native contact [56]. The number of the non-native contacts between the $A \beta$ monomers in the five ensembles averaged over 1000 frames are given at Figure $3 C$. The $\mathrm{CU}$ molecules at a higher concentration decrease the number of the non-native contacts in the $\mathrm{A} \beta$ ensemble by $16 \%$, while the decrease caused by other ligands varied between $2 \%$ for 12 FA and $4 \%$ for $12 \mathrm{CU}$ and $36 \mathrm{FA}$. The reduced contacts between the $\mathrm{A} \beta$ monomers are due to the intercalation of many $C U$ molecules bound inside the $A \beta$ nucleus (Figure 4).

\subsection{Curcumin Decreases the Number of Hydrogen Bonds in the $A \beta_{1-42}$ Ensemble}

The number of hydrogen bonds averaged over 1000 frames of the five $A \beta$ ensembles are plotted at Figure 3D. Here again, $\mathrm{CU}$ at higher concentration decreases the number of H-bonds the most. The $\mathrm{CU}$ molecules bound internally disrupt the pre-existing $\mathrm{H}$-bonds between the $\mathrm{A} \beta$ monomers and/or prevent the formation of new ones (Figure 4B,C). As expected, FA as an anion and H-bond acceptor also decreases the number of $\mathrm{H}$-bonds by replacing the peptide residues in some of them (Figure 4D,E).

In total, between 2191 and $2840 \mathrm{H}$-bonds were formed in the ensembles during the $1 \mu \mathrm{MD}$ simulation (Table 1). Of them, 73-90\% were between the $A \beta$ chains, $10-26 \%$ were between $A \beta$ and ligands, and $0.15-4 \%$ were between ligands. In the presence of 12 and $36 \mathrm{CU}$ molecules, the average lifetimes of the $\mathrm{H}$-bonds between the $\mathrm{A} \beta$ peptides were $41.7 \mathrm{~ns}$ and $36.4 \mathrm{~ns}$, respectively, $39.05 \mathrm{~ns}$ on average. The corresponding lifetimes for FA anions were $33.9 \mathrm{~ns}$ and $38 \mathrm{~ns}$, on average $35.95 \mathrm{~ns}$. The lifetimes of the $\mathrm{H}$-bonds between $\mathrm{A} \beta$ peptides and ligands were on average $14.55 \mathrm{~ns}$ for $\mathrm{CU}$ and $5.7 \mathrm{~ns}$ for FA. The H-bonds formed between ligands lived on average $9.8 \mathrm{~ns}$ for $\mathrm{CU}$ and $2.05 \mathrm{~ns}$ for FA. It is clearly evident that $\mathrm{CU}$ decreases the number of $\mathrm{H}$-bonds between $\mathrm{A} \beta$ s without affecting their lifetimes, and it stays bound longer to $A \beta$ chains and to other $C U$ molecules than FA anions do. The lifetimes of $\mathrm{H}$-bonds in the $\mathrm{A} \beta$ ensembles are given in detail in Figure $\mathrm{S} 4$.

In $71 \%$ of the $\mathrm{H}$-bonds with $\mathrm{A} \beta$ peptides, $\mathrm{CU}$ acts as an $\mathrm{H}$-bond donor (Table 1) through the phenolic $\mathrm{OH}$ groups and the enol group, which interacts with the side chains of Asp1, Arg5, Asp7, Asp23 and the backbone carbonyl oxygens of Gly9, Lys28, and Leu34. In 29\% of the H-bonds, CU is a $\mathrm{H}$-bond acceptor through the keto O-atom such as in the bond with the guanidino group of Arg5 or in the bond with the backbone $\mathrm{N}$-atom of Lys28. In contrast, the FA acts mainly as an H-bond acceptor ( $82 \%$ in average) through the phenolic and carboxy O-atoms.

Table 1. Number, percentage, and lifetime of hydrogen bonds formed between A $\beta$ peptides, between $\mathrm{A} \beta$ peptides and ligands, and between ligands calculated over 1000 frames (1000 ns).

\begin{tabular}{cccccc}
\hline Hydrogen Bonds & $\mathbf{1 2} \mathbf{A} \boldsymbol{\beta}$ & $\mathbf{1 2} \mathbf{A} \boldsymbol{\beta}+\mathbf{1 2} \mathbf{C U}$ & $\mathbf{1 2} \mathbf{A} \boldsymbol{\beta}+\mathbf{3 6} \mathbf{C U}$ & $\mathbf{1 2} \mathbf{A} \boldsymbol{\beta}+\mathbf{1 2} \mathbf{F A}$ & $\mathbf{1 2} \mathbf{A} \boldsymbol{\beta}+\mathbf{3 6} \mathbf{~ F A}$ \\
\hline Total & 2191 & 2304 & 2692 & 2632 & 2840 \\
Between A $\beta$ peptides & $2191(100 \%)$ & $2010(87 \%)$ & $2041(76 \%)$ & $2356(90 \%)$ & $2074(73 \%)$ \\
Average lifetime (ns) & 38 & 41.7 & 36.4 & 33.9 & 38 \\
Between A $\beta$ and ligands & - & $277(12 \%)$ & $545(20 \%)$ & $272(10 \%)$ & $738(26 \%)$ \\
Average lifetime (ns) & - & 14.3 & 14.8 & 7.2 & 4.2 \\
Ligand is a donor & - & $197(71 \%)$ & $386(71 \%)$ & $46(17 \%)$ & $139(19 \%)$ \\
Ligand is an acceptor & - & $80(29 \%)$ & $159(29 \%)$ & $226(83 \%)$ & $599(81 \%)$ \\
Between ligands & - & $17(1 \%)$ & $106(4 \%)$ & $4(0.15 \%)$ & $28(1 \%)$ \\
Average lifetime (ns) & - & 8.3 & 11.3 & 2.5 & 1.6 \\
\hline
\end{tabular}

\section{Discussion}

In the present study, the primary nucleation of $12 \mathrm{~A} \beta_{1-42}$ peptides was modeled by molecular dynamics in saline at $37^{\circ} \mathrm{C}$ for $1 \mu \mathrm{s}$. CU is a well-known inhibitor of $\mathrm{A} \beta$ self-assembly [58]. At pH 7.4, it is a neutral hydrophobic molecule that is slightly soluble in water (Table 2). The enol form of CU has 11 rotatable bonds, $3 \mathrm{HB}$ donors, and $6 \mathrm{HB}$ acceptors. CU has poor bioavailability (up to 1\%) [59] 
requiring high doses (from 2 to $12 \mathrm{~g}$ ) to achieve therapeutic concentrations [60]. It crosses the blood-brain barrier (BBB), binds to $\mathrm{A} \beta$ peptides, and blocks the aggregation and fibril formation in vitro and in vivo [31]. Even more, $C U$ increases the phagocytosis of $A \beta$ peptides, leading to the effective clearance of plaques from the brain of patients with Alzheimer's disease [31]. As a diferuloylmethane, CU could be considered as consisting of two FA molecules. FA is the most abundant phenolic acid in whole grain wheat $[61,62]$. It has strong antioxidant capacity $[63,64]$ and positively affects inflammation, diabetes, cancer, aging, and neurodegeneration [65-67]. FA is a weak acid that is freely soluble in water with four rotatable bonds, two HB donors, and four HB acceptors (Table 2). At $\mathrm{pH} 7.4$, the anionic form dominates. As in CU, FA has poor bioavailability [68] but crosses the BBB [69]. Reinke et al. [70] have found that two aromatic rinds are required for the inhibition of $A \beta$ aggregation, and the optimal linker between them should be rigid (up to two rotatable bonds) with a length between 8 and $16 \AA$. Accordingly, the linker in the enol form of CU consists of seven carbon atoms; five of them are in the $\mathrm{sp}^{2}$ state and two are in $\mathrm{sp}^{3}$, corresponding to two rotatable bonds. The linker length is $12 \AA$. FA contains only one aromatic ring and is a weaker inhibitor of $A \beta$ aggregation than $C U$.

Table 2. Physicochemical and ADME (adsorption, distribution, metabolism and excretion) properties of curcumin (CU) and ferulic acid (FA).

\begin{tabular}{|c|c|c|}
\hline Property & Curcumin (CU) & Ferulic Acid (FA) \\
\hline Molecular weight $(\mathrm{g} / \mathrm{mol})^{a}$ & 370.38 & 194.18 \\
\hline Solublity $(\mathrm{mg} / \mathrm{L})^{\mathrm{b}}$ & 3.12 & 780 \\
\hline $\log \mathrm{P}^{\mathrm{a}}$ & 2.52 & 1.64 \\
\hline $\mathrm{pK}_{\mathrm{a}} \mathrm{a}$ & $9.73 ; 10.02 ; 13.3$ & $4.04 ; 10.22$ \\
\hline Polar surface area $(\AA)^{a}$ & 96.22 & 66.76 \\
\hline Free rotatable bonds ${ }^{a}$ & 11 & 4 \\
\hline H-bond donors ${ }^{a}$ & 3 & 2 \\
\hline H-bond acceptors ${ }^{\mathrm{a}}$ & 6 & 4 \\
\hline $\begin{array}{c}\mathrm{IC}_{50} \mu \mathrm{M} \text { (inhibition of } \mathrm{A} \beta_{1-42} \\
\text { aggregation) }\end{array}$ & $0.8^{\mathrm{c}}$ & $5.5^{\mathrm{d}}$ \\
\hline Bioavailability \% e & $0.47-1$ & 1 \\
\hline Half-life (h) & $12.85^{\mathrm{f}}$ & $1 \mathrm{~g}$ \\
\hline BBB permeability & Yes $^{f}$ & Yes $g$ \\
\hline
\end{tabular}

\footnotetext{
a Calculated by ACD/Labs (ACD/ChemSketch, version 2020.1.0); ${ }^{\text {P }}$ PubChem [44]; ${ }^{\mathrm{c}}$ [31]; ${ }^{\mathrm{d}}$ [43]; ${ }^{\mathrm{e}}$ DrugBank [71]; f [68]; g [72].
}

It was found that the $\mathrm{IC}_{50}$ values for the inhibition of $\mathrm{A} \beta$ aggregation are $0.8 \mu \mathrm{M}$ for $\mathrm{CU}$ and $5.5 \mu \mathrm{M}$ for FA (Table 2). In the present study, $C U$ was used as a referent inhibitor of $A \beta$ nucleation, while FA was used as a referent weak inhibitor, and the effects of both compounds on the primary nucleation of $A \beta_{1-42}$ peptides were studied. As the process of primary nucleation takes several days in vitro and decades in vivo [73], in order to accelerate the in silico simulation, the systems in the present study were modeled to contain molecules in high concentrations: from 9.3 to $31.2 \mathrm{mM}$. In $10.4 \mathrm{mM}$ solution of $\mathrm{A} \beta$ peptides, the nucleation proceeded in $300 \mathrm{~ns}$. A compact nucleus was formed with a micelle-like architecture. A similar, micelle-like architecture with a hydrophobic core and polar surface was observed in the Monte Carlo simulations of $A \beta_{1-40}$ and $A \beta_{1-42}$ monomers [74]. Based on NMR analysis, Roche et al. [75] found that the self-association of $A \beta_{1-42}$ peptides into toxic oligomers is driven by intermolecular interactions between the hydrophobic regions of the peptides instead of elevated propensities of the monomeric species to adopt $\beta$-strand-like conformations.

The addition of ligands in ratios 1:1 and 1:3 accelerated the process dose-dependently. However, the cores that were formed were bigger with up to a $20 \%$ increase in SASA. In them, the A $\beta$ chains were less flexible and more disordered. In addition, the ligands decreased the number of non-native contacts and hydrogen bonds between the peptides. Interestingly, the presence of ligands in the ensembles did not affect the longevity of the H-bonds between the peptide chains. More than half of them were 
short-living (less than $10 \mathrm{~ns}$ ), one third lived between 10 and $100 \mathrm{~ns}$, and only 12\% were long-living (more than $100 \mathrm{~ns}$ ).

CU binds tightly to $A \beta$ peptides by a wide variety of intermolecular interactions: hydrogen bonds, hydrophobic interactions, $\pi-\pi$ stacking, and cation $-\pi$ attraction. Up to $20 \%$ of the hydrogen bonds in the ensembles were formed between the $\mathrm{CU}$ molecules and the $\mathrm{A} \beta$ peptides. Although $\mathrm{CU}$ contains more $\mathrm{HB}$ acceptors than $\mathrm{HB}$ donors, in $71 \%$ of the $\mathrm{HB}$, it acted as a donor. The average lifetimes of the CU-A $\beta$ H-bonds were between 14.3 and 14.8 ns. The longest-living HBs (454-506 ns) were with Asp1. CU made $\pi-\pi$ interactions with the aromatic residues in A $\beta$ (Phe4, Tyr10, Phe19, and Phe20) and cation $-\pi$ interactions with the cationic residues (Arg5, Lys16, and Lys28).

FA binds loosely to A $\beta$ peptides. At the end of the $1 \mu$ s simulation, between $25 \%$ and $50 \%$ of the FA molecules were flanking freely around the peptides. The rest were bound to $A \beta$ by short-living H-bonds (lifetimes between 4.2 and $7.2 \mathrm{~ns}$ ), hydrophobic interactions, $\pi-\pi$ stacking with the aromatic residues, and cation $-\pi$ interactions with the cationic residues.

\section{Conclusions}

In conclusion, both ligands $\mathrm{CU}$ and FA affect the process of primary nucleation of $\mathrm{A} \beta 1-42$ peptides, but the effects of $C U$ are more prominent. The $C U$ molecules intercalate among the $A \beta$ chains and bind tightly to them by H-bonds, hydrophobic, $\pi-\pi$, and cation $-\pi$ interactions. In the presence of $C U$, the primary nucleus is bigger, while the $\mathrm{A} \beta$ peptides are less flexible and more disordered, making fewer non-native contacts and $\mathrm{H}$-bonds. The observed interactions act synergistically and explain at an atomistic level the better inhibitory activity of $C U$ on $A \beta$ aggregation than that of FA. Taken regularly, $\mathrm{CU}$ is able to inhibit the process of primary nucleation of $\mathrm{A} \beta$ peptides and thus to prevent or at least to delay the onset of neurodegenerative disorders such as Alzheimer's disease.

Supplementary Materials: The following are available online at http://www.mdpi.com/2218-273X/10/9/1323/s1. Figure S1. RMSDs (left graphs) and RMSFs per residue (right graphs) averaged over 1000 frames (1000 ns) for of $12 \mathrm{~A} \beta$ monomers (grey), $12 \mathrm{~A} \beta$ monomers and $12 \mathrm{CU}$ molecules (pink), $12 \mathrm{~A} \beta$ monomers and $36 \mathrm{CU}$ molecules (red), $12 \mathrm{~A} \beta$ monomers and 12 FA anions (light green), $12 \mathrm{~A} \beta$ monomers and 36 FA anions (dark green). Figure S2. RMSDs (-single run, -average of 3 runs) averaged over 50 frames (50 ns) for $12 \mathrm{~A} \beta$ monomers (grey, A), $12 \mathrm{~A} \beta$ monomers and $12 \mathrm{CU}$ molecules (pink, B), $12 \mathrm{~A} \beta$ monomers and $36 \mathrm{CU}$ molecules (red, C), $12 \mathrm{~A} \beta$ monomers and 12 FA anions (light green, D), 12 A $\beta$ monomers and 36 FA anions (dark green, E). Figure S3. Propensities of helix (A), $\beta$-turn (B) and bending (C) averaged over 1000 frames (1000 ns) for of $12 \mathrm{~A} \beta$ monomers (grey), $12 \mathrm{~A} \beta$ monomers and $12 \mathrm{CU}$ molecules (pink), $12 \mathrm{~A} \beta$ monomers and $36 \mathrm{CU}$ molecules (red), $12 \mathrm{~A} \beta$ monomers and $12 \mathrm{FA}$ anions (light green), $12 \mathrm{~A} \beta$ monomers and 36 FA anions (dark green). Figure S4. Lifetimes of H-bonds between $\mathrm{A} \beta$ peptides (left pie-charts), between $\mathrm{A} \beta$ and ligards (middle pie-chart) and between ligands (right pie-charts).

Author Contributions: Conceptualization: I.D. (Irini Doytchinova); MD simulations: I.D. (Irini Doytchinova), M.A., E.S.; writing: I.D. (Irini Doytchinova); review and editing: I.D. (Irini Doytchinova), M.A., E.S., S.I., I.D. (Ivan Dimitrov). All authors have read and agreed to the published version of the manuscript.

Funding: This work was funded by the Bulgarian National Science Fund (Grant DN03/9/2016) and the Medical Science Council of the Medical University of Sofia (Grant D-118/2020).

Acknowledgments: This work was performed in the Centre of Excellence for Informatics and ICT supported by the Science and Education for Smart Growth Operational Program (2014-2020) and co-financed by the European Union through the European Structural and Investment funds (Grant No BG05M2OP001-1.001-0003).

Conflicts of Interest: The authors declare no conflict of interest.

\section{References}

1. Michaels, T.C.T.; Šarić, A.; Habchi, J.; Chia, S.; Meisl, G.; Vendruscolo, M.; Dobson, C.M.; Knowles, T.P.J. Chemical Kinetics for Bridging Molecular Mechanisms and Macroscopic Measurements of Amyloid Fibril Formation. Ann. Rev. Phys. Chem. 2018, 69, 273-298. [CrossRef] [PubMed]

2. Romero, D.; Aguilar, C.; Losick, R.; Kolter, R. Amyloid fibers provide structural integrity to Bacillus subtilis biofilms. Proc. Natl. Acad. Sci. USA 2010, 107, 2230-2234. [CrossRef] [PubMed]

3. Jacob, R.S.; George, E.; Singh, P.K.; Salot, S.; Anoop, A.; Jha, N.N.; Sen, S.; Maji, S.K. Cell Adhesion on Amyloid Fibrils Lacking Integrin Recognition Motif. J. Biol. Chem. 2016, 291, 5278-5298. [CrossRef] [PubMed] 
4. Matsuzaki, K.; Horikiri, C. Interactions of amyloid beta-peptide (1-40) with ganglioside-containing membranes. Biochemistry 1999, 38, 4137-4142. [CrossRef] [PubMed]

5. Zadali, R.; Ghareghozloo, E.R.; Ramezani, M.; Hassani, V.; Rafiei, Y.; Chiyaneh, S.M.; Meratan, A.A. Interactions and Membrane Permeabilization of Brain Mitochondria by Amyloid Fibrils. J. Vis. Exp. 2019, 151. [CrossRef] [PubMed]

6. Hieronymus, L.; Griffin, S. Role of Amylin in Type 1 and Type 2 Diabetes. Diabetes Educ. 2015, 41, 47S-56S. [CrossRef]

7. Guo, T.; Noble, W.; Hanger, D.P. Roles of tau protein in health and disease. Acta Neuropathol. 2017, 133, 665-704. [CrossRef]

8. Palop, J.J.; Mucke, L. Amyloid-beta-induced neuronal dysfunction in Alzheimer's disease: From synapses toward neural networks. Nat. Neurosci. 2010,13, 812-818. [CrossRef]

9. Wozniak, M.A.; Itzhaki, R.F.; Shipley, S.J.; Dobson, C.B. Herpes simplex virus infection causes cellular beta-amyloid accumulation and secretase upregulation. Neurosci. Lett. 2007, 429, 95-100. [CrossRef]

10. Eimer, W.A.; Vijaya Kumar, D.K.; Navalpur Shanmugam, N.K.; Rodriguez, A.S.; Mitchell, T.; Washicosky, K.J.; György, B.; Breakefield, X.O.; Tanzi, R.E.; Moir, R.D. Alzheimer's Disease-Associated $\beta$-Amyloid Is Rapidly Seeded by Herpesviridae to Protect against Brain Infection. Neuron 2018, 99, 56-63. [CrossRef]

11. Sulzer, D.; Edwards, R.H. The physiological role of $\alpha$-synuclein and its relationship to Parkinson's Disease. J. Neurochem. 2019, 150, 475-486. [CrossRef] [PubMed]

12. Watt, B.; van Niel, G.; Raposo, G.; Marks, M.S. PMEL: A pigment cell-specific model for functional amyloid formation. Pigment. Cell Melanoma Res. 2013, 26, 300-315. [CrossRef] [PubMed]

13. Hardy, J.A.; Higgins, G.A. Alzheimer's disease: The amyloid cascade hypothesis. Science 1992, 256, $184-185$. [CrossRef] [PubMed]

14. Irwin, D.J.; Lee, V.M.; Trojanowski, J.Q. Parkinson's disease dementia: Convergence of $\alpha$-synuclein, tau and amyloid- $\beta$ pathologies. Nat. Rev. Neurosci. 2013, 14, 626-636. [CrossRef]

15. Sigurdson, C.J.; Bartz, J.C.; Glatzel, M. Cellular and Molecular Mechanisms of Prion Disease. Ann. Rev. Pathol. 2019, 14, 497-516. [CrossRef]

16. Bharadwaj, P.; Wijesekara, N.; Liyanapathirana, M.; Newsholme, P.; Ittner, L.; Fraser, P.; Verdile, G. The Link between Type 2 Diabetes and Neurodegeneration: Roles for Amyloid- $\beta$, Amylin, and Tau Proteins. J. Alzheimer's Dis. JAD 2017, 59, 421-432. [CrossRef]

17. Tumblin, A.; Tailor, A.; Hoehn, G.T.; Mack, A.K.; Mendelsohn, L.; Freeman, L.; Xu, X.; Remaley, A.T.; Munson, P.J.; Suffredini, A.F.; et al. Apolipoprotein A-I and serum amyloid A plasma levels are biomarkers of acute painful episodes in patients with sickle cell disease. Haematologica 2010, 95, 1467-1472. [CrossRef]

18. Ilie, I.M.; Caflisch, A. Simulation Studies of Amyloidogenic Polypeptides and Their Aggregates. Chem. Rev. 2019, 119, 6956-6993. [CrossRef]

19. Lazo, N.D.; Grant, M.A.; Condron, M.C.; Rigby, A.C.; Teplow, D.B. On the nucleation of amyloid beta-protein monomer folding. Protein Sci. 2005, 14, 1581-1596. [CrossRef]

20. Törnquist, M.; Michaels, T.; Sanagavarapu, K.; Yang, X.; Meisl, G.; Cohen, S.; Knowles, T.; Linse, S. Secondary nucleation in amyloid formation. Chem. Commun. 2018, 54, 8667-8684.

21. Eisele, Y.S.; Monteiro, C.; Fearns, C.; Encalada, S.E.; Wiseman, R.L.; Powers, E.T.; Kelly, J.W. Targeting protein aggregation for the treatment of degenerative diseases. Nat. Rev. Drug Discov. 2015, 14, 759-780. [CrossRef] [PubMed]

22. Ono, K.; Hasegawa, K.; Naiki, H.; Yamada, M. Curcumin has potent anti-amyloidogenic effects for Alzheimer's beta-amyloid fibrils in vitro. J. Neurosci. Res. 2004, 75, 742-750. [CrossRef] [PubMed]

23. Bhat, A.; Mahalakshmi, A.M.; Ray, B.; Tuladhar, S.; Hediyal, T.A.; Manthiannem, E.; Padamati, J.; Chandra, R.; Chidambaram, S.B.; Sakharkar, M.K. Benefits of curcumin in brain disorders. BioFactors 2019, 45, 666-689. [CrossRef] [PubMed]

24. World Health Organization. World Life Expectancy. Report 2018. Available online: https://www. worldlifeexpectancy.com/ (accessed on 15 September 2020).

25. Krishnaswamy, K. Traditional Indian spices and their health significance. Asia Pac. J. Clin. Nutr. 2008, 17, 265-268.

26. Pulido-Moran, M.; Moreno-Fernandez, J.; Ramirez-Tortosa, C.; Ramirez-Tortosa, M. Curcumin and Health. Molecules 2016, 21, 264. [CrossRef] 
27. Kunnumakkara, A.B.; Bordoloi, D.; Padmavathi, G.; Monisha, J.; Roy, N.K.; Prasad, S.; Aggarwal, B.B. Curcumin, the golden nutraceutical: Multitargeting for multiple chronic diseases. Br. J. Pharmacol. 2017, 174, 1325-1348. [CrossRef]

28. Kocaadam, B.; Şanlier, N. Curcumin, an active component of turmeric (Curcuma longa), and its effects on health. Crit. Rev. Food Sci. Nutr. 2017, 57, 2889-2895. [CrossRef]

29. Kim, Y.; Clifton, P. Curcumin Cardiometabolic Health and Dementia. Int. J. Environ. Res. Public Health 2018, 15, 2093. [CrossRef]

30. Di Meo, F.; Margarucci, S.; Galderisi, U.; Crispi, S.; Peluso, G. Curcumin Gut Microbiota and Neuroprotection. Nutrients 2019, 11, 2426. [CrossRef]

31. Yang, F.S.; Lim, G.P.; Begum, A.N.; Ubeda, O.J.; Simmons, M.R.; Ambegaokar, S.S.; Chen, P.P.; Kayed, R.; Glabe, C.G.; Frautschy, S.A.; et al. Curcumin Inhibits Formation of Amyloid beta Oligomers and Fibrils, Binds Plaques, and Reduces Amyloid in vivo. J. Biol. Chem. 2005, 280, 5892-5901. [CrossRef]

32. Bondi, M.L.; Montana, G.; Craparo, E.F.; Picone, P.; Capuano, G.; Di Carlo, M.; Giammona, G. Ferulic Acid-Loaded Lipid Nanostructures as Drug Delivery Systems for Alzheimers Disease: Preparation, Characterization and Cytotoxicity Studies. Curr. Nanosci. 2009, 5, 26-32. [CrossRef]

33. Yanagisawa, D.; Ibrahim, N.F.; Taguchi, H.; Morikawa, S.; Hirao, K.; Shirai, N.; Soabe, T.; Tooyama, I. Curcumin derivative with the substitution at C-4 position, but not curcumin, is effective against amyloid pathology in APP/PS1 mice. Neurobiol. Aging 2015, 36, 201-210. [CrossRef] [PubMed]

34. Cox, K.H.; Pipingas, A.; Scholey, A.B. Investigation of the effects of solid lipid curcumin on cognition and mood in a healthy older population. J. Psychopharmacol. 2015, 29, 642-651. [CrossRef] [PubMed]

35. Small, G.W.; Siddarth, P.; Li, Z.; Miller, K.J.; Ercoli, L.; Emerson, N.D.; Martinez, J.; Wong, K.P.; Liu, J.; Merrill, D.A.; et al. Memory and Brain Amyloid and Tau Effects of a Bioavailable Form of Curcumin in Non-Demented Adults: A Double-Blind, Placebo-Controlled 18-Month Trial. Am. J. Geriatr Psychiatry 2018, 26, 266-277. [CrossRef] [PubMed]

36. Zhao, L.N.; Chiu, S.W.; Benoit, J.; Chew, L.Y.; Mu, Y. The effect of curcumin on the stability of A $\beta$ dimers. J. Phys. Chem B 2012, 116, 7428-7435. [CrossRef]

37. Awasthi, M.; Singh, S.; Pandey, V.P.; Dwivedi, U.N. Modulation in the conformational and stability attributes of the Alzheimer's disease associated amyloid-beta mutants and their favorable stabilization by curcumin: Molecular dynamics simulation analysis. J. Biomol. Struct. Dyn. 2018, 36, 407-422. [CrossRef]

38. Ngo, S.T.; Li, M.S. Curcumin binds to A $\beta 1-40$ peptides and fibrils stronger than ibuprofen and naproxen. J. Phys. Chem B 2012, 116, 10165-10175. [CrossRef]

39. Kundaikar, H.S.; Degani, M.S. Insights into the Interaction Mechanism of Ligands with A $\beta 42$ Based on Molecular Dynamics Simulations and Mechanics: Implications of Role of Common Binding Site in Drug Design for Alzheimer's Disease. Chem. Biol. Drug Des. 2015, 86, 805-812. [CrossRef]

40. Tavanti, F.; Pedone, A.; Menziani, M.C. Computational Insight into the Effect of Natural Compounds on the Destabilization of Preformed Amyloid- $\beta(1-40)$ Fibrils. Molecules 2018, 23, 1320. [CrossRef]

41. Jakubowski, J.M.; Orr, A.A.; Le, D.A.; Tamamis, P. Interactions between Curcumin Derivatives and Amyloid- $\beta$ Fibrils: Insights from Molecular Dynamics Simulations. J. Chem. Inf. Model. 2020, 60, 289-305. [CrossRef]

42. Bajda, M.; Filipek, S. Computational approach for the assessment of inhibitory potency against beta-amyloid aggregation. Bioorg. Med. Chem. Lett. 2017, 27, 212-216. [CrossRef] [PubMed]

43. Ono, K.; Hirohata, M.; Yamada, M. Ferulic acid destabilizes preformed $\beta$-amyloid fibrils in vitro. Biochem. Biophys. Res. Commun. 2005, 336, 444-449. [CrossRef] [PubMed]

44. Kim, S.; Chen, J.; Cheng, T.; Gindulyte, A.; He, J.; He, S.; Li, Q.; Shoemaker, B.A.; Thiessen, P.A.; Yu, B.; et al. PubChem 2019 update: Improved access to chemical data. Nucleic Acids Res. 2019, 47, D1102-D1109. [CrossRef] [PubMed]

45. Yanagisawa, D.; Shirai, N.; Amatsubo, T.; Taguchi, H.; Hirao, K.; Urushitani, M.; Morikawa, S.; Inubushi, T.; Kato, M.; Kato, F.; et al. Relationship between the tautomeric structures of curcumin derivatives and their Abeta-binding activities in the context of therapies for Alzheimer's disease. Biomaterials 2010, 31, 4179-4185. [CrossRef]

46. Rao, P.P.; Mohamed, T.; Teckwani, K.; Tin, G. Curcumin Binding to Beta Amyloid: A Computational Study. Chem. Biol. Drug Des. 2015, 86, 813-820. [CrossRef]

47. Wang, J.M.; Wolf, R.M.; Caldwell, J.W.; Kollman, P.A.; Case, D.A. Development and Testing of a General Amber Force Field. J. Comput. Chem. 2004, 25, 1157-1174. [CrossRef] 
48. Jakalian, A.; Bush, B.L.; Jack, D.B.; Bayly, C.I.F. Efcient generation of high-quality atomic charges. AM1-BCC model: I. Method. J. Comput. Chem. 2000, 21, 132-146. [CrossRef]

49. Case, D.A. Te Amber Biomolecular Simulation Programs. J. Comput. Chem. 2005, 26, 1668-1688. [CrossRef]

50. Crescenzi, O.; Tomaselli, S.; Guerrini, R.; Salvadori, S.; D’Ursi, A.M.; Temussi, P.A.; Picone, D. Solution structure of the Alzheimer amyloid beta-peptide (1-42) in an apolar microenvironment. Similarity with a virus fusion domain. Eur. J. Biochem. 2002, 269, 5642-5648. [CrossRef]

51. Adelman, S.A.; Doll, J.D. Generalized Langevin equation approach for atom/solid-surface scattering: Collinear atom/harmonic chain model. J. Chem. Phys. 1974, 61, 4242-4245. [CrossRef]

52. Berendsen, H.J.C.; Postma, J.P.M.; van Gunsteren, W.F.; DiNola, A.; Haak, J.R. Molecular dynamics with coupling to an external bath. J. Chem. Phys. 1984, 81, 3684-3690. [CrossRef]

53. Maier, J.A. f14SB: Improving the Accuracy of Protein Side Chain and Backbone Parameters from f99SB. J. Chem. Teory Comput. 2015, 11, 3696-3713. [CrossRef] [PubMed]

54. Darden, T.; York, D.; Pedersen, L. Particle mesh Ewald: An N-log(N) method for Ewald sums in large systems. J. Chem Phys. 1993, 98, 10089. [CrossRef]

55. Ciccotti, G.; Ryckaert, J.P. Molecular dynamics simulation of rigid molecules. Comput. Phys. Rep. 1986, 4, 346-392. [CrossRef]

56. Case, D.A.; Ben-Shalom, I.Y.; Brozell, S.R.; Cerutti, D.S.; Cheatham, T.E., III; Cruzeiro, V.W.D.; Darden, T.A.; Duke, R.E.; Ghoreishi, D.; Gilson, M.K.; et al. AMBER; University of California: San Francisco, CA, USA, 2018.

57. Roe, D.R.; Cheatham, T.E. PTRAJ and CPPTRAJ: Sofware for Processing and Analysis of Molecular Dynamics Trajectory Data. J. Chem. Teory Comput. 2013, 9, 3084-3095. [CrossRef]

58. Mishra, S.; Palanivelu, K. The effect of curcumin (turmeric) on Alzheimer's disease: An overview. Ann. Indian Acad. Neurol. 2008, 11, 13-19. [CrossRef]

59. Pawar, Y.B.; Munjal, B.; Arora, S.; Karwa, M.; Kohli, G.; Paliwal, J.K.; Bansal, A.K. Bioavailability of a lipidic formulation of curcumin in healthy human volunteers. Pharmaceutics 2012, 4, 517-530. [CrossRef]

60. Lao, C.D.; Ruffin, M.T.; Normolle, D.; Heath, D.D.; Murray, S.I.; Bailey, J.M.; Boggs, M.E.; Crowell, J.; Rock, C.L.; Brenner, D.E. Dose escalation of a curcuminoid formulation. BMC Complement. Altern. Med. 2006, 6, 10.

61. Mattila, P.; Pihlava, J.M.; Hellstro"m, J. Contents of phenolic acids, alkyl- and alkenylresorcinols, and avenanthramides in commercial grain products. J. Agricult. Food Chem. 2005, 53, 8290-8295. [CrossRef]

62. Moore, J.; Hao, Z.; Zhou, K.; Luther, M.; Costa, J.; Yu, L. Carotenoid, tocopherol, phenolic acid, and antioxidant properties of Maryland-grown soft wheat. J. Agricult. Food Chem. 2005, 52, 6649-6657. [CrossRef]

63. Graf, E. Antioxidant potential of ferulic acid. Free Rad. Biol. Med. 1992, 13, 435-448. [CrossRef]

64. Mateo Anson, N.; Berg, v.d.R.; Havenaar, R.; Bast, A.; Haenen, G.R.M.M. Ferulic acid from aleurone determines the antioxidant potency of wheat grain (Triticum aestivum L.). J. Agricult. Food Chem. 2008, 56, 5589-5594. [CrossRef] [PubMed]

65. Ou, S.; Kwok, K.C. Ferulic acid: Pharmaceutical functions, preparation and applications in foods. J. Sci. Food Agric. 2004, 84, 1261-1269. [CrossRef]

66. Srinivasan, M.; Sudheer, A.R.; Menon, V.P. Ferulic acid: Therapeutic potential through its antioxidant property. J. Clin. Biochem. Nutr. 2007, 40, 92-100. [CrossRef]

67. Barone, E.; Calabrese, V.; Mancuso, C. Ferulic acid and its therapeutic potential as a hormetin for age-related diseases. Biogerontology 2009, 10, 97-108. [CrossRef]

68. Zhao, Z.; Moghadasian, M.H. Chemistry, natural sources, dietary intake and pharmacokinetic properties of ferulic acid: A review. Food Chem. 2008, 109, 691-702. [CrossRef]

69. Wu, K.; Wang, Z.Z.; Liu, D.; Qi, X.R. Pharmacokinetics, brain distribution, release and blood-brain barrier transport of Shunaoxin pills. J. Ethnopharmacol. 2014, 151, 1133-1140. [CrossRef]

70. Reinke, A.A.; Gestwicki, J.E. Structure-activity relationships of amyloid beta-aggregation inhibitors based on curcumin: Influence of linker length and flexibility. Chem. Biol. Drug Des. 2007, 70, 206-215. [CrossRef]

71. Wishart, D.S.; Feunang, Y.D.; Guo, A.C.; Lo, E.J.; Marcu, A.; Grant, J.R.; Sajed, T.; Johnson, D.; Li, C.; Sayeeda, Z.; et al. DrugBank 5.0: A major update to the DrugBank database for 2018. Nucleic Acids Res. 2018, 46, D1074-D1082. [CrossRef]

72. Modi, M.A.; Kale, N.V.; Patel, J.H.; Varia, R.D.; Modi, F.D.; Vihol, P.D. Pharmacokinetics of ferulic acid following oral administration ethyl ferulate alone and in combination with piperine in rats. Ann. Phytomed. 2019, 8, 194-198. [CrossRef] 
73. Balchin, D.; Hayer-Hartl, M.; Hartl, F.U. In vivo aspects of protein folding and quality control. Science 2016. [CrossRef] [PubMed]

74. Vitalis, A.; Caflisch, A. Micelle-like architecture of the monomer ensemble of Alzheimer's amyloid- $\beta$ peptide in aqueous solution and its implications for A $\beta$ aggregation. J. Mol. Biol. 2010, 403, 148-165. [CrossRef] [PubMed]

75. Roche, J.; Shen, Y.; Lee, J.H.; Ying, J.; Bax, A. Monomeric A $\beta 1-40$ and A $\beta 1-42$ Peptides in Solution Adopt Very Similar Ramachandran Map Distributions That Closely Resemble Random Coil. Biochemistry 2016, 55, 762-775. [CrossRef] [PubMed]

(C) 2020 by the authors. Licensee MDPI, Basel, Switzerland. This article is an open access article distributed under the terms and conditions of the Creative Commons Attribution (CC BY) license (http://creativecommons.org/licenses/by/4.0/). 